\title{
Design of a Plastic Shredder Machine
}

\author{
Nuri Aryani, Dede Buchori, and Albertus Budi Setiawan
}

\begin{abstract}
Waste is one of the problems that still unsolved especially for plastic waste. If the handling of plastic waste cannot be done well, it will have effect for the long period. The effect of plastic waste is environment problems such as: chain food disturb, contaminate ground water, air pollution, extinction anima, poisonous soil, and act. One of the handling for plastic waste is recycling. It starts with separating plastic waste by kind of plastic. The next step is crush it until it becomes small flakes. The Small flakes can be directly used for making product such as pot, filler material for mixing with road asphalt or plastic granulate for making a product by injection mold or extraction. In order to handle plastic waste into small flakes, plastic shredder can be used to realize the making of prototype of plastic shredder machine. It starts with design process. The design process of the prototype of plastic shredder machine uses the method of design Pahl and Beitz method that consists of design and describes job, design product concept, embodiment design, and design of detail. The plastic shredder machine consists of blades or cutter, transmission element with the shape of spur gear, electric motor, and body of machine. The kind of waste plastic for shred is LDPE, HDPE, PP, PSBased for the design of plastic shredder machine can produce small flake with the dimension of about $10 \mathrm{~mm}$ long and $1 \mathrm{~mm}$ wide.
\end{abstract}

Keywords-Plastics, Shredder Machine, Design, Waste.

\section{INTRODUCTION}

Plastic waste is an inorganic waste that is unable to be composted naturally and can be harmful for the environment if it is not controlled well such as; pollute the air, water and soil, disturb the food chain, kill the animals and many more. To solve this problem, plastic shedder machine is going to be made to help the recycling process which converts plastic into other product such as vase, paving block and others.

Plastic shredder machine consists of some functional parts that work simultaneously to recycle plastic which is inverted into small parts of the plastic. Plastic shredder machine consists of cutters, shafts, gears, a coupling, a motor, and a hopper.

\section{STEPS TO DESIGN PAHL AND BEITZ}

The steps to design Pahl and Beitz method consist of 4 phases which are divided into some steps in each phase [1], they are:

a. Designing and describing job

b. Designing the concept of the product

c. Designing the embodiment of the product

d. Detailing design

Nuri Aryani, Dede Buchori, and Albertus Budi Setiawan are with Department of Manufacturing Engineering, Politeknik Manufaktur Negeri Bandung, Bandung, 40135, Indonesia. E-mail: Nuriaryani.na@gmail.com.
TABLE 1.

SPECIFICATION List OF Plastic SHREDder Machine

\begin{tabular}{cl}
\hline \hline DD/W & Terms \\
\hline W & Simple shape \\
D & Small dimension \\
W & Easy to transport \\
D & Easy to use in environment \\
D & Rustproof \\
W & Spare parts available \\
D & Safe to use \\
D & Easy to assemble \\
D & Easy to operate \\
D & Easy to shredder plastic \\
W & Relatively cheap \\
W & Easy to maintain \\
\hline \hline
\end{tabular}

Where:

D: demand $\quad$ W: wishes

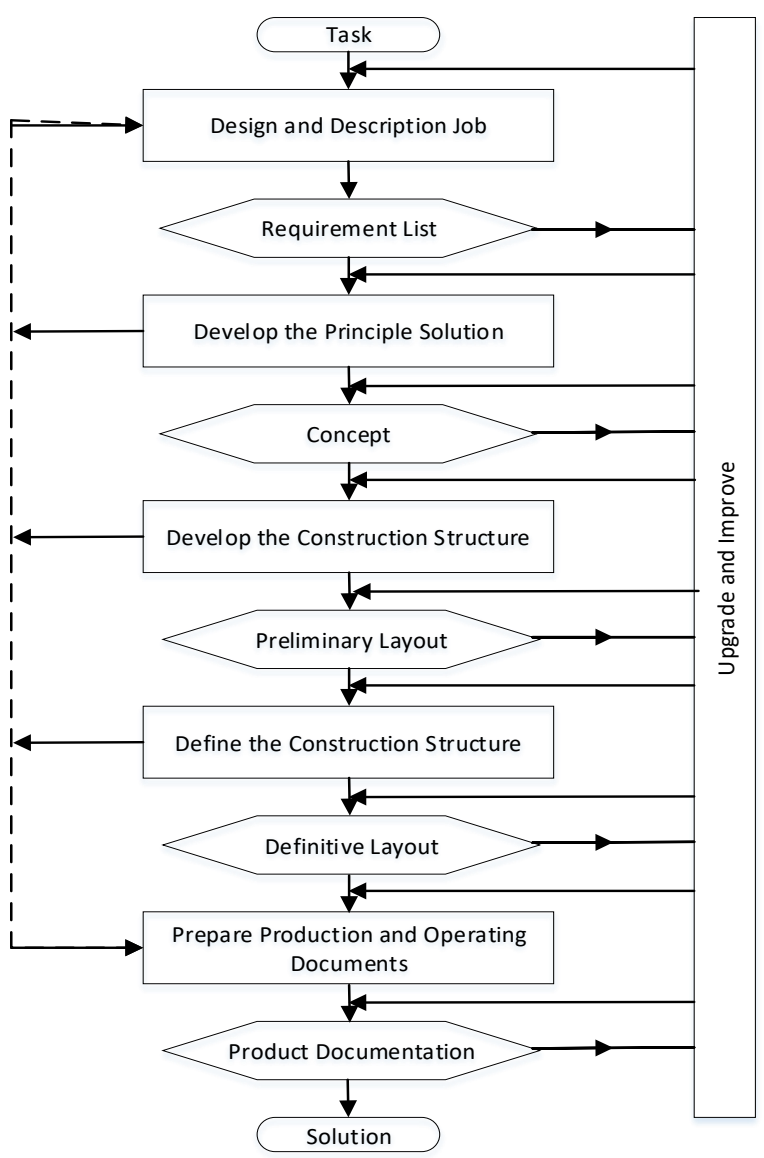

Figure 1. Flow Chart Design Process.

\section{A. Designing and Describing Job}

The process of designing machine can be started with acknowledging things that are needed in operation or in using the machine and it will be developed into some function blocks that describe the way in and way out. 


\section{B. Developing the Main Solution}

Here is the flow chart that shows the steps of process breaking plastic from the choosing type of the plastic that will be processed until collecting the shredder of the plastic.

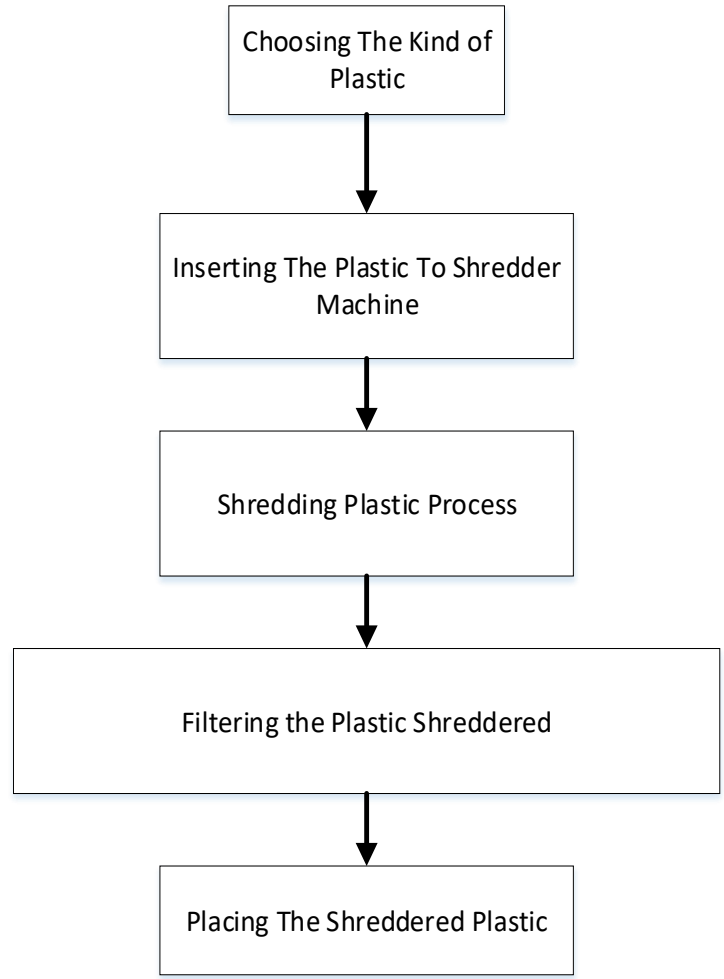

Figure 2. Shredded Plastic Process.

The processing steps of shredder plastic such as in diagram 2. then can be explained into function block diagram.

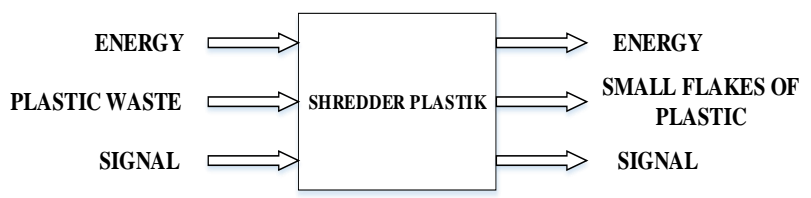

Figure 3. Function block diagram.

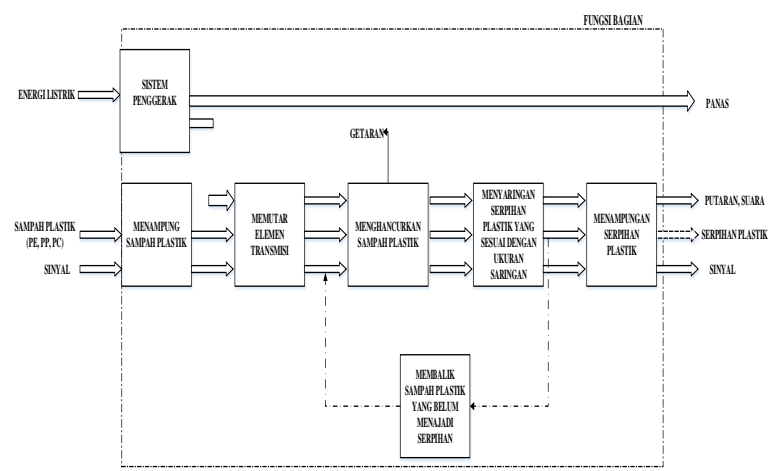

Figure 4. Sub-Function of Plastic Shredder Machine

\section{Product Concept}

The product concept is use to make sure that the concept is better then other.

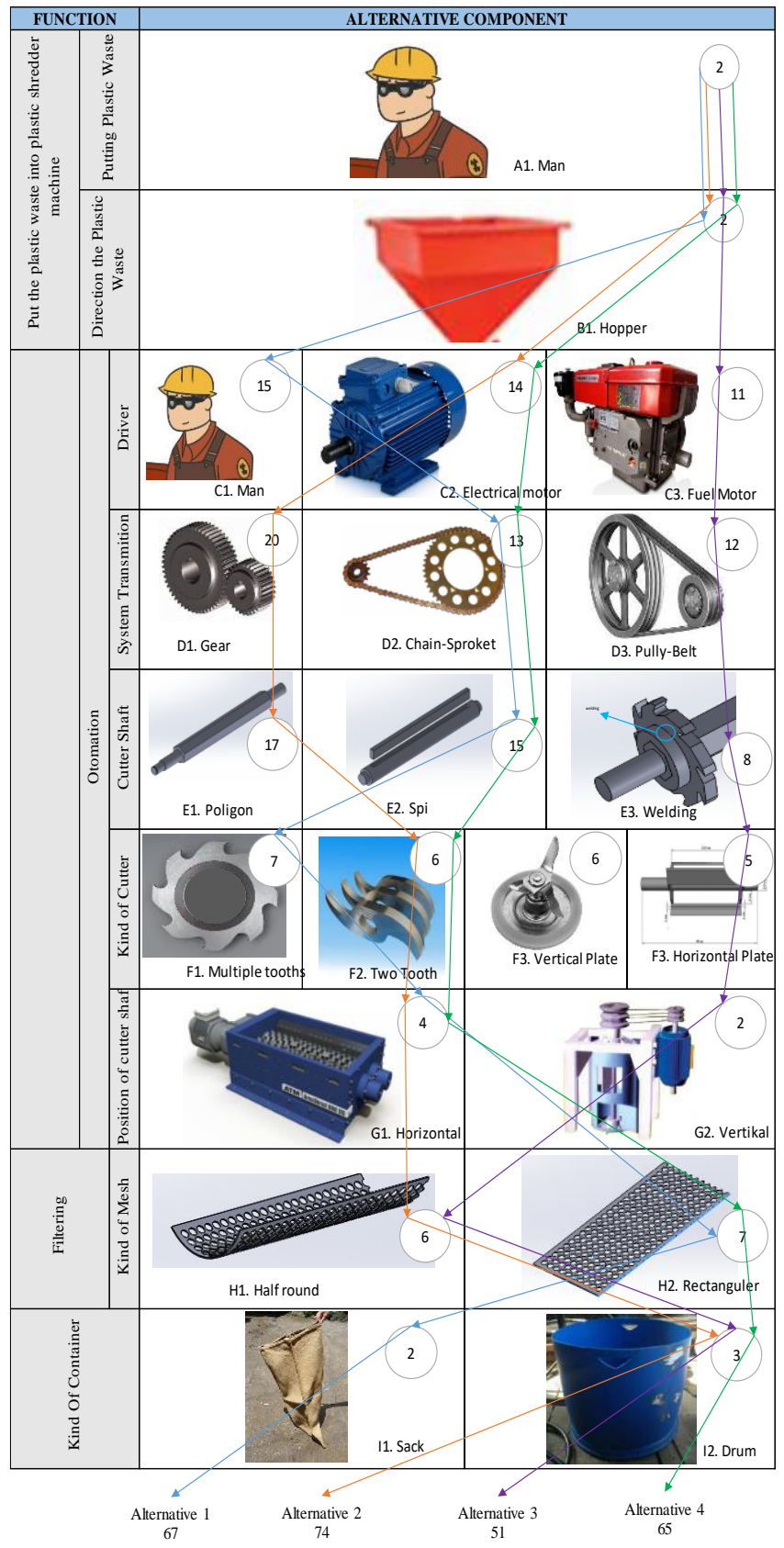

Figure 5. Alternative Component.

Alternative $1=\mathrm{A} 1(2)-\mathrm{B} 1(2)-\mathrm{C} 1(15)-\mathrm{D} 2(13)-\mathrm{E} 2$ (15) - F1 (7) - G1 (4) - H2 (7) - I1 (2) = 67

Alternative 2 = A1 (2) - B1 (2) - C2 (14) - D1 (20) - E1 (17) - F2 (6) - G1 (4) - H1 (6) - I2 (3) = 74

Alternative $3=\mathrm{A} 1(2)-\mathrm{B} 1(2)-\mathrm{C} 3(11)-\mathrm{D} 3(12)-\mathrm{E} 3(8)$ $-\mathrm{F} 3(5)-\mathrm{G} 2(2)-\mathrm{H} 1(6)-\mathrm{I} 2(3)=51$

Alternative $4=\mathrm{A} 1(2)-\mathrm{B} 1(2)-\mathrm{C} 2(14)-\mathrm{D} 2(13)-\mathrm{E} 2$ $(15)-\mathrm{F} 2(6)-\mathrm{G} 1(4)-\mathrm{H} 2(7)-\mathrm{I} 2(3)=65$

Based on the alternative concept of the product, one alternative has been chosen as alternative 2 with value of 74 . Then, it is expanded into full concept of the product. 
International Conference on Engineering, Advance Science and Industrial Application (ICETESIA) 2018 September 6-7 2018, Institut Teknologi Sepuluh Nopember, Surabaya, Indonesia

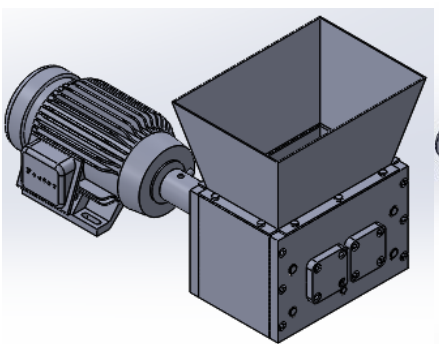

(a)

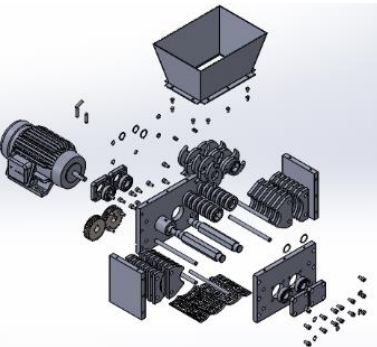

(b)
Figure 6. Alternative Concept Product (a) Concept Product assembling, (b) exploded view of Concept Product

\section{Choosing Structure of the Product}

Based on the analysis, some maintenance elements is obtained as follows.

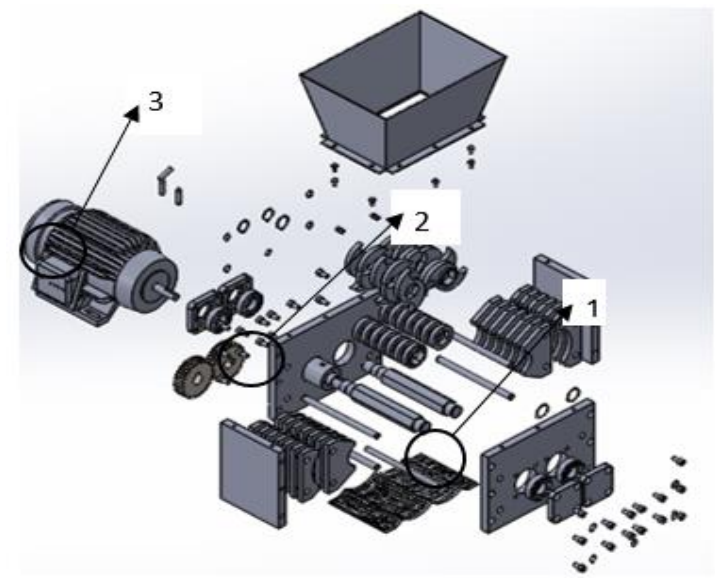

Figure 7. Component is change.

TABLE 2.

SOME CHANGERS IN THE CONSTRUCTION IN THE ELEMENTS

Notes
fasten the process
of making,
reduce the price
of making the
component and
fasten the
assemble

Changes that happen to some elements which is shown in the diagram are expected to be able to maximize the function of the machine.

\section{E. Document of the Product}

The process of choosing the product construction that has been analyzed into some components that changes happen and gives the best result then it is documented where as done as follows.

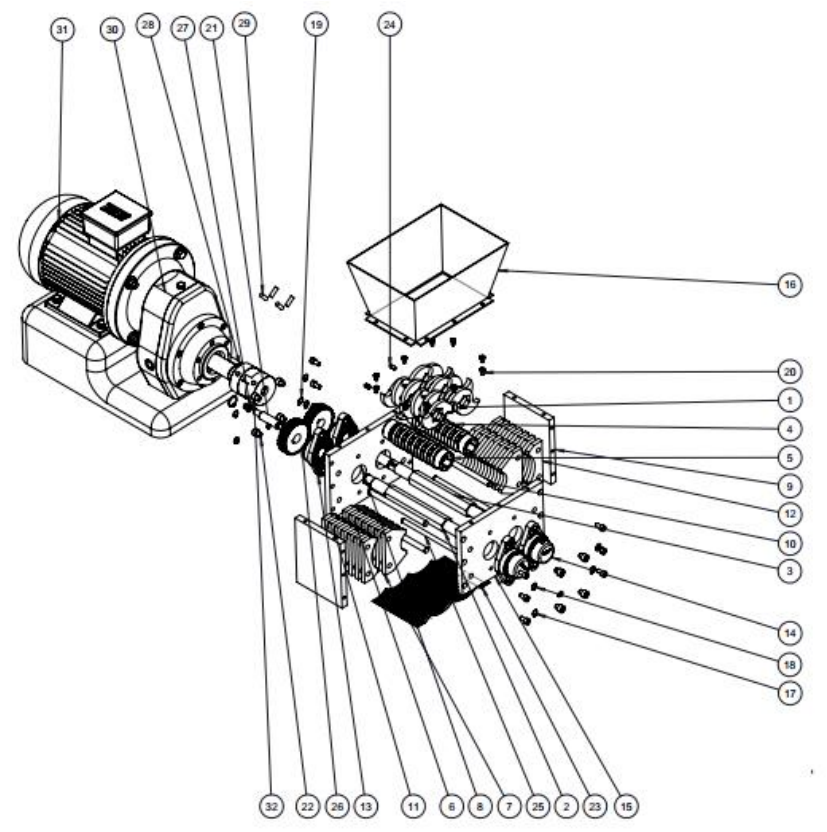

Figure 8. Exploded view of Plastic Shredder Machine.

Where:

$$
\begin{array}{llll}
1 & \text { Cutter } & 17 & \text { Circlip Side Poros } \\
2 & \text { Hexagonal Shaft } & 18 & \text { Circlip Poros Mesh } \\
3 & \text { Hexagonal Shaft Motor } & 19 & \text { Circlip Roda Gigi } \\
4 & \text { Spacer } & 20 & \text { Bolt Hexagonal M6 } \\
5 & \text { Bush } & 21 & \text { Holder Idler } \\
6 & \text { Side Cutter } & 22 & \text { Baut Inbus M8 } \\
7 & \text { Side Cutter Step } & 23 & \text { Mesh } \\
8 & \text { Front Plate } & 24 & \text { Spi Roda Gigi } \\
9 & \text { Side Plate } & 25 & \text { Shaft of Mesh } \\
10 & \text { Side Poros } & 26 & \text { Gear } \\
11 & \text { Side Spacer } & 27 & \text { wesher } \\
12 & \text { Side Spacer Step } & 28 & \text { Coupling Flexible } \\
13 & \text { Bearing Units } & 29 & \text { Pen } \\
14 & \text { Cover Bearing Units } & 30 & \text { Gear Box } \\
15 & \text { Back Plate } & 31 & \text { Electrical Motor } \\
16 & \text { Hopper } & 32 & \text { Bolt Inbus M10 }
\end{array}
$$

\section{DATA CALCULATION AND ANALYSIS}

\section{A. Force}

This construction have two kind of force are tension force and shear force.

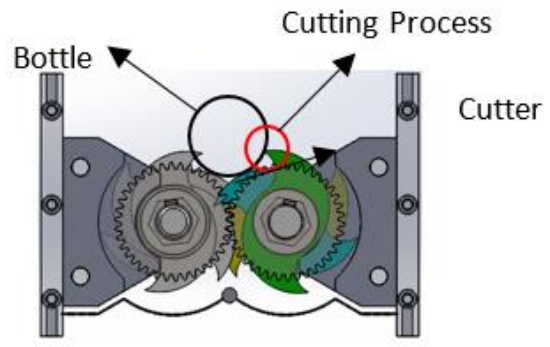

Figure 9. Tension Force. 


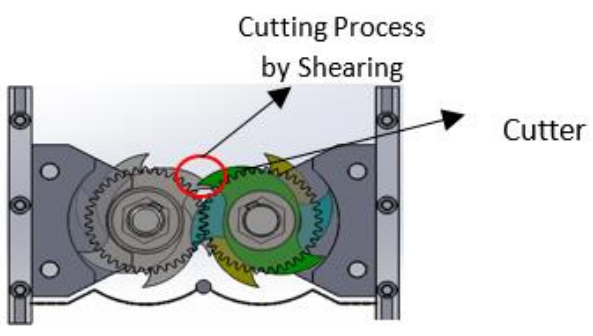

Figure 10. Shear Force.

TABLE 3. Data of Tensile StRength of Plastic

\begin{tabular}{cc}
\hline \hline Material & $\begin{array}{c}\text { Tensile Strength } \\
{[\mathbf{M p a}]}\end{array}$ \\
\hline LDPE & 18.0000 \\
HDPE & 30.5180 \\
PP & 35.5350 \\
PS & 2.4000 \\
\hline \hline
\end{tabular}

The biggest of tensile strength on the table [2][3] is 35.535 [MPa]. The cutter width (1) is 10 [mm], the bottle thickness (t) is 0.5 [mm], $\varepsilon$ ot is 0.65 (from table the relative amount of penetration of the upper blade into the material), $\operatorname{tg} \varphi$ is 1 , $\mathrm{vc}_{\text {plastic }}$ is $140[\mathrm{~m} / \mathrm{min}]$.

The formula shear force for blades [4] used is

$$
\mathrm{F}=0.6 \times \operatorname{UTS} \times \varepsilon \cot \frac{T^{2}}{2 \times \operatorname{tg} \varphi}
$$

Furthermore the formula tension force for blades used is

$$
\sigma=\frac{P}{A}
$$

The shear force is $1.732[\mathrm{~N}]$ per tooth and the tension force is $\mathrm{P}(\mathrm{Ft})=177.675[\mathrm{~N}]$ per tooth.

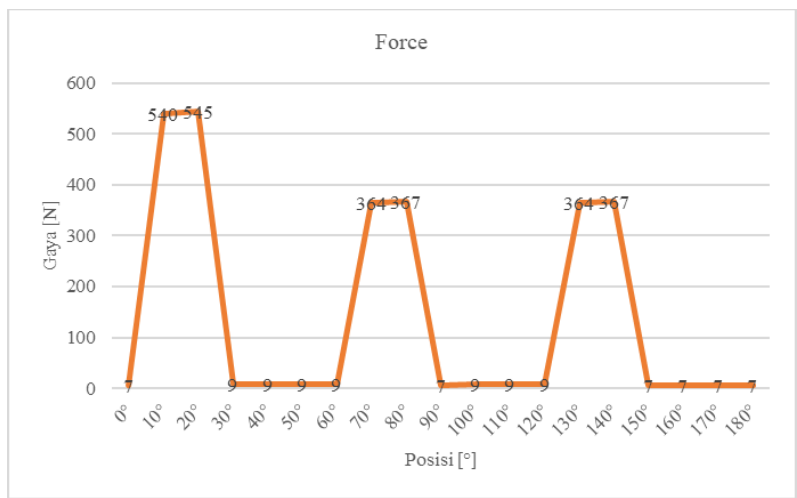

Figure 11. Force at the Shaft

The big force is occur the position $20^{\circ}$ is 545.149 [N].

\section{B. The Torque of Machine}

The force at the cutter makes torque and the diameter is $100[\mathrm{~mm}]$. the formula of torque [5] used is

$$
\mathrm{T}=\mathrm{F} \times \mathrm{d}
$$

In this case the torque of machine is 27.257 [Nm]. When the engine rotates to produce friction, heat, etc. thus, the torque that has been obtained is add to losses of $25 \%$ from the previous torque results is $34.07125[\mathrm{Nm}]$.

\section{The Torque of Motor}

Motor Torque is the torque needed to rotate the engine. When machine operated the $\mathrm{V}_{\mathrm{PET}}$ is $140[\mathrm{~m} / \mathrm{min}]$, Diameter of cutter is 100 [mm], $\Delta t$ is 1 [s], the speed motor is 1600 [rpm], the Rpm machine is 400 [rpm], ratio (i) is $4, \alpha=$ $46.67\left[\frac{\mathrm{rad}}{\mathrm{s}^{2}}\right]$, part of moment inertia when rotate at speed 1600 [rpm] is 0.0376339 , part of moment inertia when rotate at speed $400[\mathrm{rpm}]$ is 0.0566217 . the formula to calculate torque of motor [6] is

$$
\begin{aligned}
& \mathrm{Ek}_{\mathrm{total}}=\frac{1}{2} J_{1} \omega_{1}{ }^{2}+\frac{1}{2} J_{2} \omega_{2}{ }^{2} \\
& \Sigma \mathrm{T}=J \alpha
\end{aligned}
$$

The torque is $10.44[\mathrm{Nm}]$.

\section{The Power of Motor}

The formula the power of motor [7] used is

$$
\mathrm{P}=\frac{T \times 2 \times \pi \times n}{60}
$$

Based on calculations, the power needed to cut plastic is $2.34[\mathrm{Hp}]$.

\section{E. Shaft Strength}

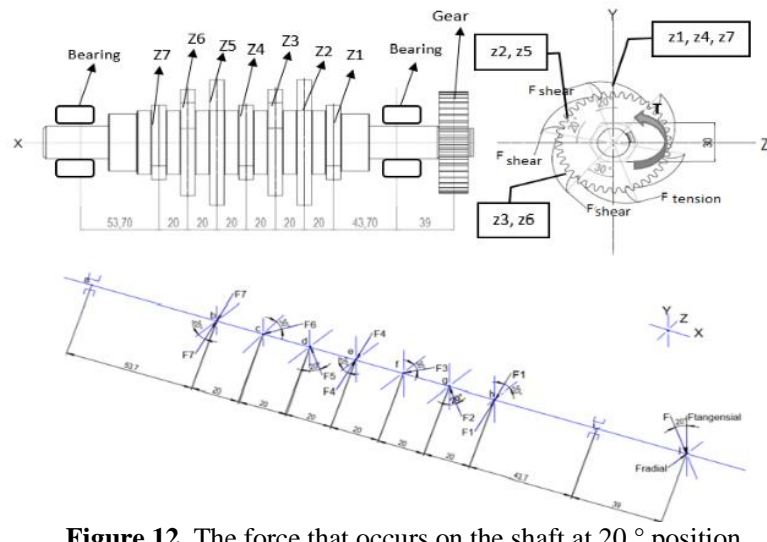

Figure 12. The force that occurs on the shaft at $20^{\circ}$ position.

F. Force analysis of $x-z$ plane.

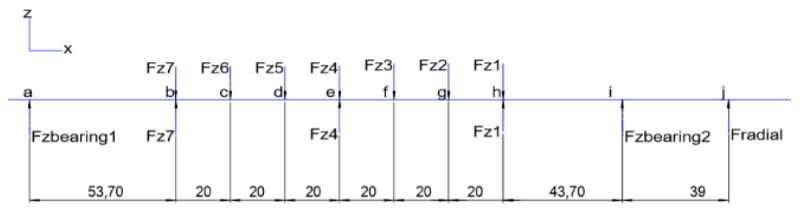

Figure 13. Force analysis of $x-z$ plane.

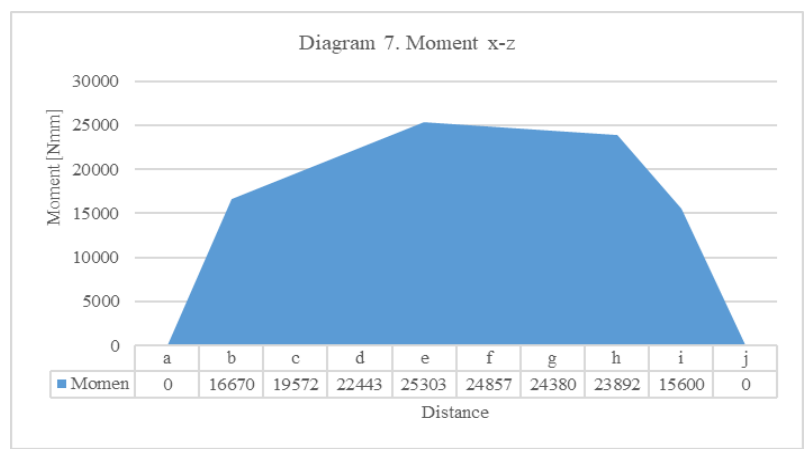

Figure 14. Moment $x-z$. 
International Conference on Engineering, Advance Science and Industrial Application (ICETESIA) 2018 September 6-7 2018, Institut Teknologi Sepuluh Nopember, Surabaya, Indonesia

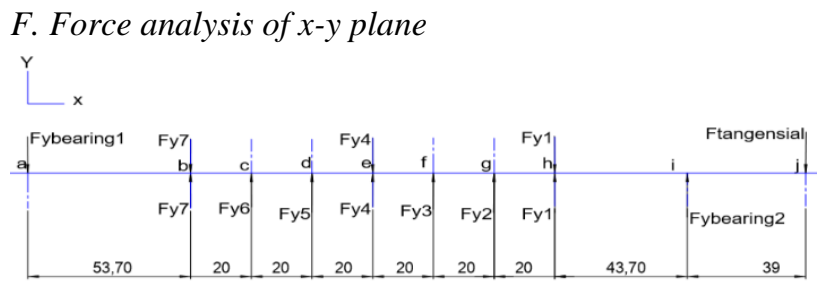

Figure 15. The force that occurs on the $x-y$ plane

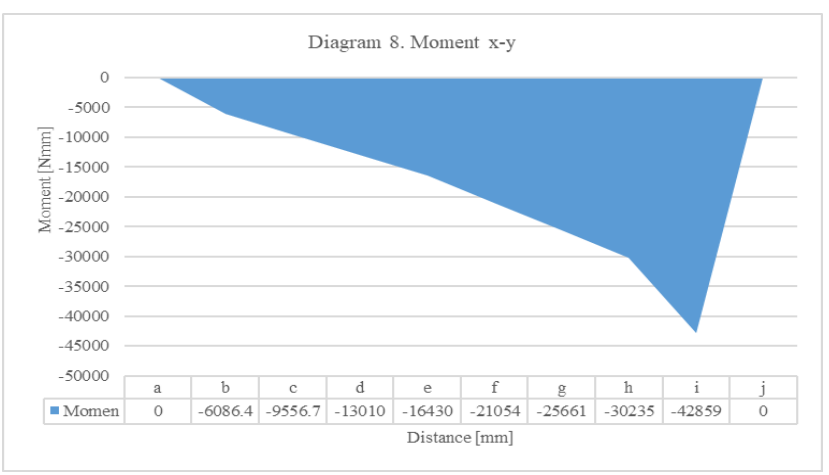

Figure 16. Moment x-y.

The biggest moment is at point $\mathrm{i}\left(\Sigma \mathrm{M}_{\mathrm{i}}\right)$ is 45609.663 [Nmm], and the stress of moment is $29.748\left[\mathrm{~N} / \mathrm{mm}^{2}\right]$

\section{G. Torque Analysis}

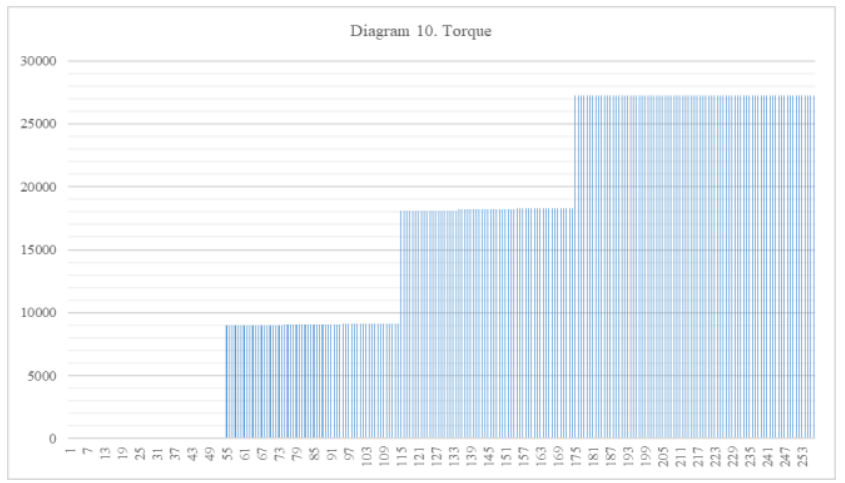

Figure 17. Torque Analysis

The biggest moment is at point $\mathrm{i}\left(\Sigma \mathrm{M}_{\mathrm{i}}\right)$ is $27257.45[\mathrm{Nmm}]$, and the stress of torque is $8.889\left[\mathrm{~N} / \mathrm{mm}^{2}\right]$

\section{H. Safety Factor for Shaft}

The stress allowed from ST37 is $370\left[\mathrm{~N} / \mathrm{mm}^{2}\right]$. The safety factor for shaft is 11.489 .

\section{Safety Factor for Gear}

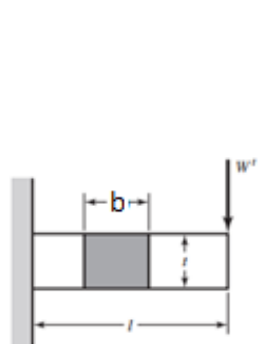

(a)

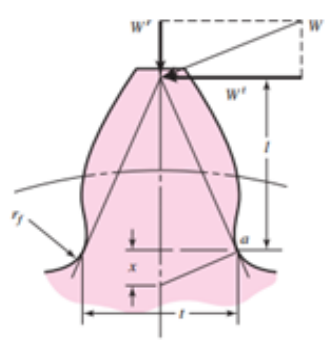

(b)

The stress allowed from $\mathrm{Vcn}$ is $900\left[\mathrm{~N} / \mathrm{mm}^{2}\right]$.

The formula for stress of gear [8] used is

$$
\begin{aligned}
& \mathrm{k}_{\mathrm{v}}=\frac{3.56+\sqrt{v}}{3.56} \\
& \sigma=\frac{k_{v} w^{t}}{b m Y}
\end{aligned}
$$

The safety factor for gear is 1.681 .

The data bearing [9] from catalogue are know $\mathrm{C}$ is 14 [kN] $=14000[\mathrm{~N}], \mathrm{P}_{\mathrm{u}}$ is $0.335[\mathrm{kN}]$, diameter is $25[\mathrm{~mm}], \mathrm{Da}=$ $63.5[\mathrm{~mm}], \mathrm{P} 1$ is $330.467[\mathrm{~N}], \mathrm{P} 2$ is $1403.665[\mathrm{~N}], \mathrm{n}=400$ $[\mathrm{rpm}], \mathrm{V}_{\mathrm{c}}=41.867[\mathrm{~mm} / \mathrm{s}]$, Operating hours permitted for counting machines $=10000-25000$ [operating hours]. The formula for bearing life is

$$
\begin{aligned}
\mathrm{L}_{10} & =\left[\frac{C}{\mathrm{P}}\right]^{p} \\
\mathrm{~L}_{\mathrm{nmh}} & =\frac{10^{6}}{60 \mathrm{n}} \mathrm{L}_{10}
\end{aligned}
$$

The bearing life for bearing 1 is 3168024.792 [operating hours], and for bearing 2 is 1240234.211 [operating hours]. The two of bearing which are greater than the operating hours allowed.

\section{Closing}

The design for plastic shredder machine uses Pahl and Beitz method, that consist of design and describing job, design product concept, embodiment machine, and design of detail. The design that is chosen is alternative 2, where the value is 74. The Plastic waste that will be cut is LDPE, HDPE, PP and PS. The power that is needed to cut plastic is 2.34 [Hp], and all of part have safety factor above 1 so it is safe to use.

\section{REFERENCES}

H. Harsokoessoemo, Pengantar Perancangan Teknik. Bandung: ITS Press, 2004.

C. Harper, Modern Plastics Handbook. New York: Mc Graw Hill, 2000.

W. Smith, Foundations of Materials Science and Engineering. New York: Mc Graw Hill, 2011.

V. Boljanovic, Sheet Metal Forming Processes and Die Design. New York: Industrial Press, 2004.

J. Meriam, Engineering Mechanics Statics. USA: Joh Wiley \& Sons, 2008.

Sutarno, Fisika Untuk Universitas. Yogyakarta: Graha Ilmu, 2013.

J. Gere, Machanics of Materials. USA: Bill Stenquist, 2004.

R. G. Budynas, J. K. Nisbett, and J. E. Shigley, Shigley's mechanical engineering design, 9th. New Delhi: McGraw-Hill, 2011.

SKF, "Rolling Bearing.” 2016.

Figure 18. The force that occurs on Gear. 